\section{Reproductive Disturbances of Romney Ewe Lambs grazed on Red Clover (Trifolium pratense) Pastures}

ON March 10, 1958, 111 Romney owe lambs (group $A$ ) which had grazed continuously since weaning (December 12, 1957) on pastures dominant in red clover were joined with an additional 92 Romney ewe lambs (group $B$ ) for studies of their breeding season. This latter group had grazed, since weaning (December 11, 1957), on perennial rye-grass-white clover pastures. Vasectomized, ochred rams were run with these lambs from March 17, 1958, all being grazed together on perennial rye-grass-white clover pastures. All lambs were weighed on March 19, group $A$ and group $B$ having the same average live weight $(71 \mathrm{lb}$.$) . On the same day, that is, within$ two days of joining with teasers, 29 lambs from group $A$ but none from group $B$ were found to have been marked. This sudden onset of cestrus from one group of lambs was unexpected in view of the previous results ${ }^{1}$ on the breeding season of Romney ewe lambs. Owing to the relatively early age at first œestrus shown by these lambs, laparotomy was performed within five days of observed cestrus to determine whether ovulation had occurred. Both the left and right ovaries of eight lambs were examined without finding any evidence of the existence of corpora lutea. Graafian follicles of varying sizes, however, were seen on most ovaries.

Red clover ${ }^{2}$, like Australian subterranean clover $^{3}$, has been reported to contain substances with œestrogenic effects. In order to investigate whether the observed cestrus without ovulation in the lambs described earlier could have resulted from the oestrogenic activity of the red clover dominant pastures, random samples of this pasture were collected on March 25. These samples, consisting almost entirely of red clover, were freeze-dried, ground in a hammer mill and fed to 21-day-old, ovariectomized white mice in an attempt to detect the presence of substances with oestrogenic effects by the mouse uterine weight technique ${ }^{4}$. The control diet consisted of 50 per cent (by weight) barley meal and 50 per cent butter milk powder. The 'clover' diet was made up from 75 per cent (by weight) control diet and 25 per cent 'clover' pasture. Results from two feeding periods of 10 and 11 days respectively were combined and are presented in Table 1.

Table 1. The EFfects of FeEding 'Clover' DIET to Mice (SEven

\begin{tabular}{|l|c|c|}
\multicolumn{2}{|c|}{ MICE PER GROUP) } \\
\hline \multicolumn{1}{|c|}{ Treatments } & Control & 'Clover' \\
\hline Initial body-wt. (gm.) & $8 \cdot 76$ & $8 \cdot 64$ \\
Final body-wt. (gm.) & $15 \cdot 10$ & $10 \cdot 07$ \\
No. of vaginal openings & $1^{*}$ & 70.07 \\
Mean and S.D. of uterine wt. (mgm.) & $5 \cdot 36 \pm 0 \cdot 99$ & $10 \cdot 57 \pm 2 \cdot 67$ \\
\hline
\end{tabular}

* Suspected to be an artefact.

These results indicate that the 'red clover' pastures contained substances which have potent œstrogenic effects. It is also probable that ingestion of 'red clover' pastures over a period of time as occurred in the present case has induced cestrus without ovulation in the lambs. It is of interest to note that Australian workers ${ }^{5-7}$ have repeatedly pointed out that lowered fertility of breeding ewes grazing subterranean clovers was not attributable to the failure of cestrus as detected by ochred rams. If the present findings are also applicable to breeding ewes, then under certain conditions, 'œstrus without ovulation' may represent an additional complication in studies of female infertility in sheep.

Grateful acknowledgment is due to Dr. D. S. Flux, Prof. A. L. Rae and Mr. B. Thatcher for assistance and discussion.

Sheep Husbandry Department,

T. S. CH'ANG

Massey Agricultural College,

University of New Zealand,

Palmerston North, New Zealand.

Aug. 4.

${ }^{1}$ Ch'ang, T. S., and Raeside, J. I., N.Z.A.P.S., 17, 80 (1957).

${ }^{2}$ Pope, G. S., Dairy Sci. Abst., 16, 334 (1954).

${ }^{3}$ Curnow, D. H., Robinson, T. J., and Underwood, E. J., Aust. J. Exp. Biol.' and Med. Sci., 26, 171 (1948).

- Evans, J. S., Varney, R. F., and Koch, F. C., Endocrinol., 28, 747 (1941).

s Schinckel, P. G., Aust. Vet. J., 24, 289 (1948).

${ }^{6}$ Underwood, E. J., and Shier, F. L., Aust. Vet. J., 27,63 (1951).

${ }^{2}$ Underw'ood, E. J., and Shier, F. L., Aust. Vet. J., 28, 157 (1952).

\section{Molybdenum Content of Equine Liver} Tissue

The discovery that molybdenum is a component of the enzyme xanthine oxidase ${ }^{1}$ has directed interest to the presence of this element in animal tissue, particularly liver. I have found that adult horse liver tissue contains highly variable levels of molybdenum.

125 specimens of adult horse liver were obtained from a Cambridge slaughter-house during a period of eight months. The liver samples were dried at $100^{\circ} \mathrm{C}$. and the dried material analysed for molybdenum by the thiocyanate-stannous chloride method of Dick and Bingley ${ }^{2}$. The range of molybdenum content of the tissues is shown in Fig. 1.

While 109 of the 125 livers were within the range 3-19 p.p.m., five livers had molybdenum-levels of $42 \cdot 0,47 \cdot 6,54 \cdot 8,76 \cdot 4$ and $84 \cdot 6$ p.p.m. of tissue drymatter. The total ash contents of these latter five samples were within the normal range.

Comparing these figures with the data given by Underwood $^{3}$, it has been found that molybdenum accumulates in the liver to a greater extent in the horse than in cattle or sheep. The reason for the accumulation of this element is not known, but it is.

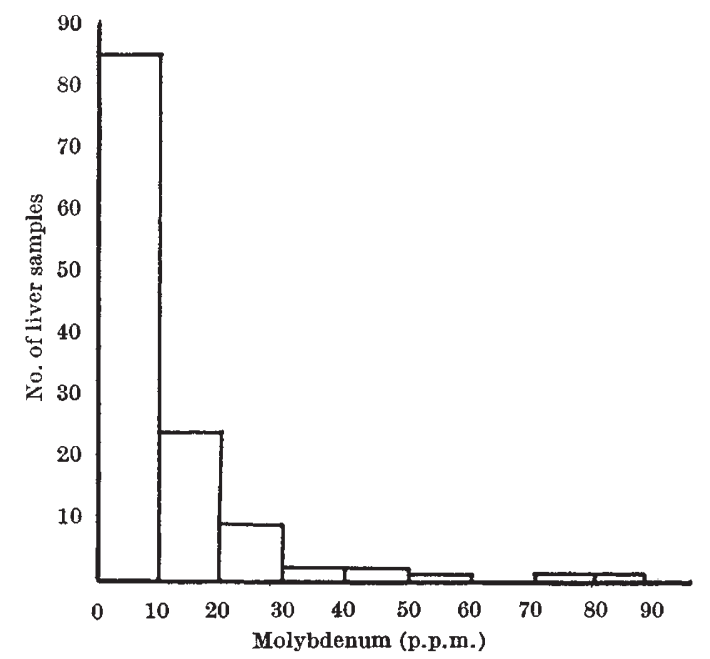

Fig. 1. Range of molybdenum contents of 125 samples of equine 